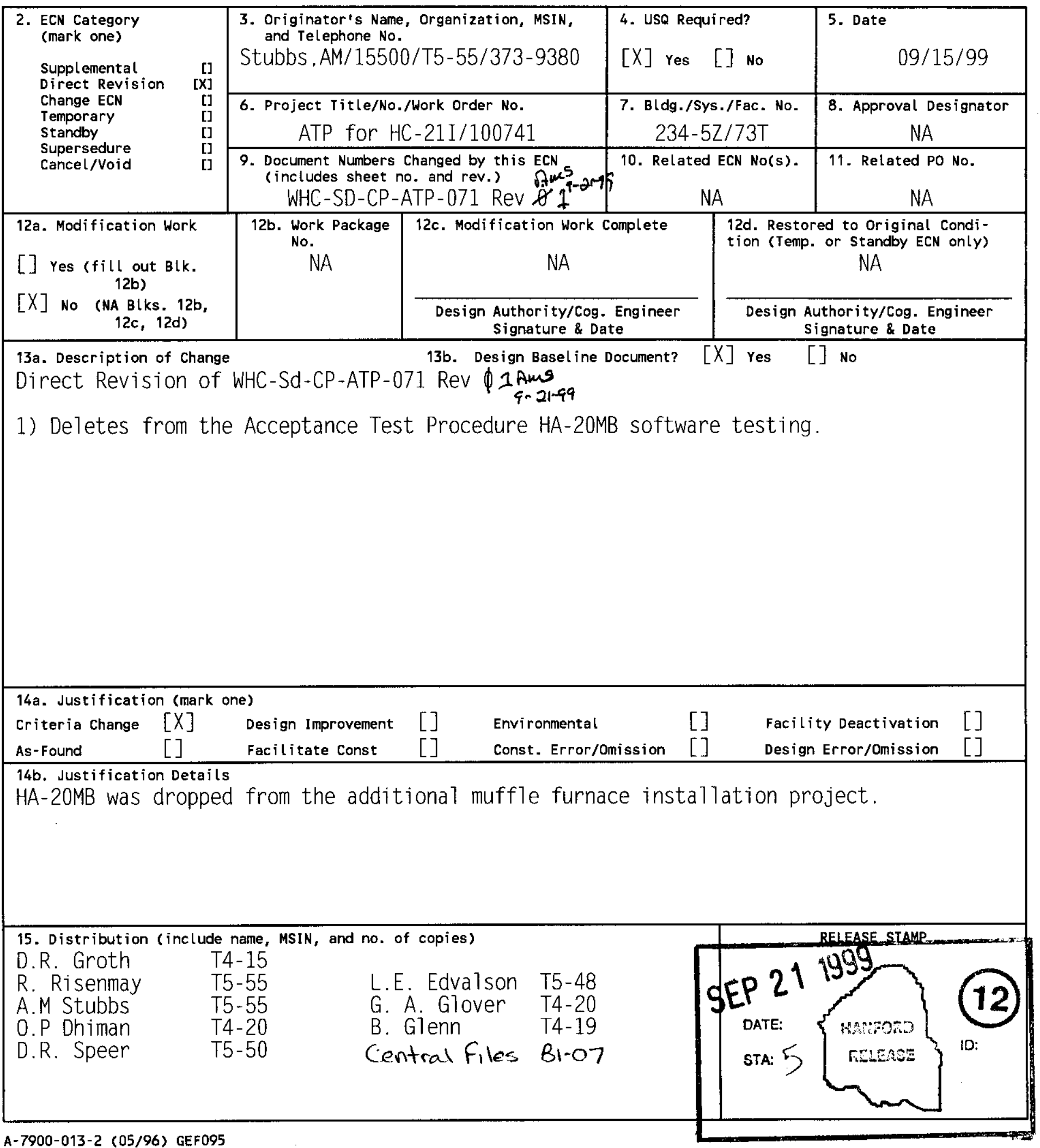




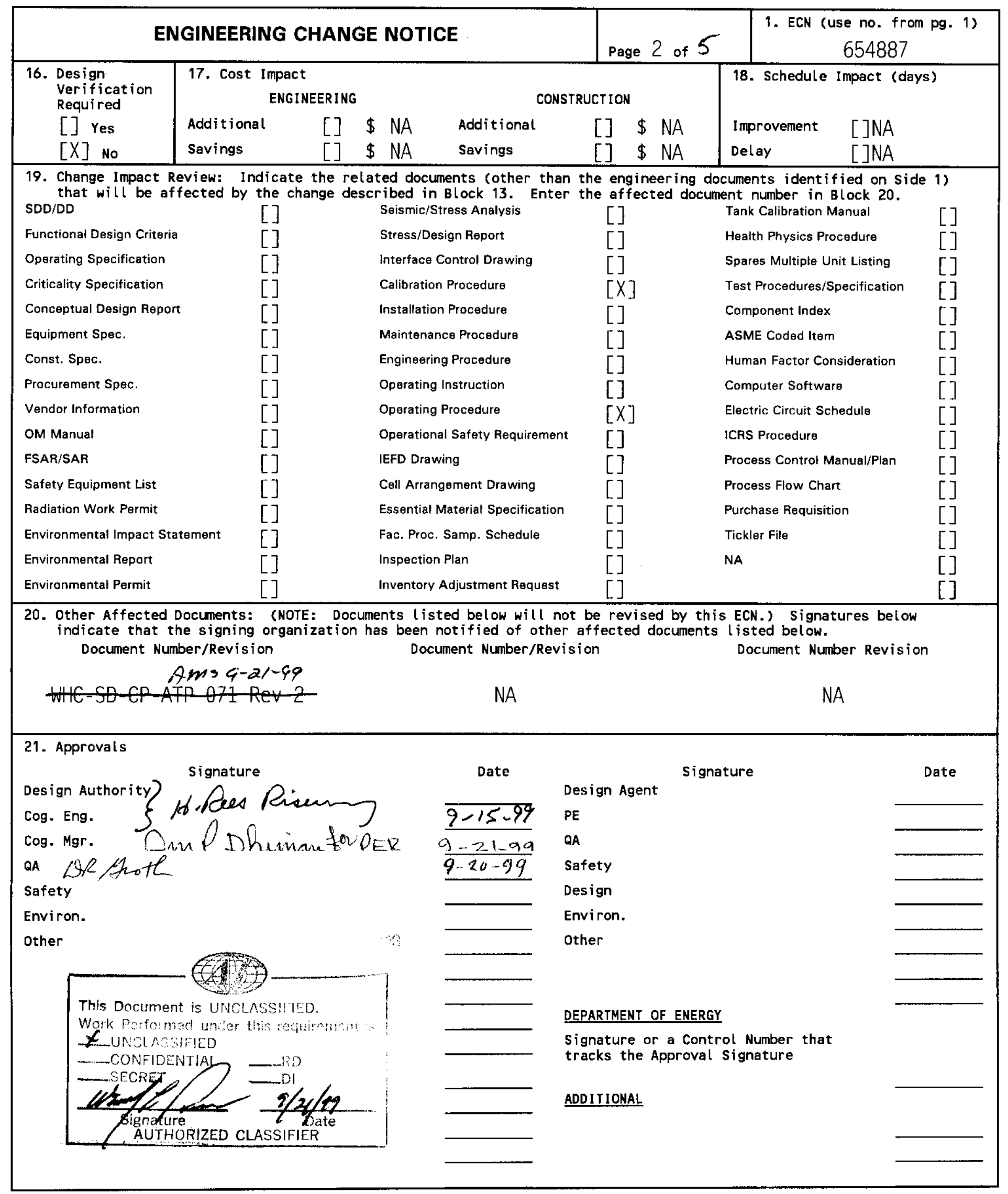




\section{UNREVIEWED SAFETY QUESTION (USQ) \\ SCREENING AND EVALUATION}

1. Identification Number:

HNF-SD-CP-ATP-071 Rev 1

USO SCREENING

Page 3 of 5

2. Title: Honeywe11 Modular Automation System Acceptance Test Procedure.

\section{DESCRIPTION:}

The Acceptance Test Procedure Describes a method to test the Honeywel1 Modular Automation System programming(PLC/MAS) using simulated inputs. The PLC programming controls the HA21 f furnaces heating cycle, off-gas vacuum pumps and monitors glovebox temperature during operation. The change to the ATP removes testing HA-20MB furnace PLC/MAS. The furnaces were never installed in HA-20MB.

INTRODUCTION:

The purpose of this Acceptance Test Procedure (ATP) is to verify the operability of the three new furnaces as controlled by the new Honeywell Modular Automation System(MAS). The Honeywell MAS is being installed in PFP to control the three thermal stabilization furnaces in glovebox HA-21I. The ATP provides instructions for testing the configuration of the Honeywell MAS at the Plutonium Finishing Plant(PFP). The test will be a field test of the analog inputs, analog outputs, and software interlocks. The interlock test wi11 check the digital input and outputs. Field equipment will not be connected for this test. Simulated signals will be used to test thermocouple. limit switch, and vacuum pump inputs to the PLC/MAS.

The following sections in HNF-SD-CP-SAR-021 Rev 1 describe the use of HA-21I and the PLC:

Section 6.4.1.1 Process Description - -

Section 6.4.1.1.1 -- Narrative Description -- The section states that thermal stabilization is performed in HA-21I and the type of feed allowed in HA-21I.

Sub-heading Process Feed -- The section states that thermal stabilization is performed in HA-21I.

Sub-heading Stabilization - - The section discusses the furnace operation in HA-21I and that the furnaces are controlled with a PLC(MAS) rather than individual controllers.

HNF-SD-CP-SAR-021 Rev 1, Appendix 9A. Plutonium Finishing Plant Hazard Evaluation, Table 9A.1.1 Item 21. The item discusses the various types of failures that could happen during the operation of HA-21I.

AFFECTED SSC: No SSC's are affected by this ATP change.

AUTHORIZATION BASIS:

The authorization basis documents considered include those 1isted in FSP-PFP-5-8, section 2.23, appendix $A$.

These are:

HNF-SD-CP-SAR-021 Rev 1 
1. Ident ification Number: HNF-SD-CP-ATP-071 Rev 1

2. Title: Honeywell Modular Automation System Acceptance Test Procedure.

\section{CONCLUSION:}

The performance of this ATP test the PLC(MAS) is within the bounds of the Plutonium Finishing Plant Authorization Basis. The use of the PLC is discussed in Chapter 6 of HNFSD-CP-SAT-021 Rev 1. All questions were answered "No", therefore, a USQ Evaluation is not required.

\section{REFERENCES:}

none

INSTRUCTIONS: Respond to each question and provide justification for each response. A restatement of the question does not constitute a satisfactory justification or basis. An adequate justification provides sufficient explanation such that an independent reviewer could reach the same conclusion based on the information provided [DOE 5480.21 , 10.e.1].

QUESTIONS

1. Does the proposed change or occurrence represent a change to the facility or procedures as described in the Authorization Basis?
[] N/A
[X] No
[] Yes/Maybe

Basis: The ATP HNF-SD-CP-ATP-071 Rev 1 provides instructions for testing the configuration of the Honeywel1 MAS at the Plutonium Finishing Plant(PFP). Section 6.4.1.1.1. Sub-heading Stabilization -- The section discusses the furnace operation in HA-21I and that the furnaces are controlled with a PLC(MAS) rather than individual controllers as used with $\mathrm{HC}-21 \mathrm{C}$. The ATP as written to verify the operability of the three new furnaces in HA-21I does not add any additional operational requirements that have not been discussed in HNF-SD-CP-SAR-021 Rev 1 . The ATP would not change the authorization basis.

2. Does the proposed change or occurrence represent conditions that have not been analyzed in the Authorization Basis? [] N/A [X] No [] Yes/Maybe

Basis: The ATP, HNF-SD-CP-ATP-071 Rev 1, activities as written will not create new conditions for the facility. since HNF-SD-CP-SAR-021 Rev 1 discusses the use of the PLC to control the HA-21I furnaces in chapter 6, Section 6.4.1.1 Process Description

\footnotetext{
Does the proposed change represent a test or experiment NOT described in the Authorization Basis that may affect the safe operation of the facility?

[] N/A [X] No [] Yes/Maybe

Basıs: The acceptance test as written, will not affect the safe operation of the facility since the controller will not be connected to any facility equipment. All inputs will be simulated and the outputs monitored.
}

4. Does the proposed change or occurrence represent a change to the Technical Safety Requirements or a reduction in the margin of safety defined in the Technical Safety Requirements?

[] N/A [X] No [] Yes/Maybe

BASIs: Performance of this ATP does not require any OSR/TSR changes. 
UNREVIEWED SAFETY QUESTION (USO)

SCREENING AND EVALUATION

1. Ident ification Number:

HNF-SD-CP-ATP-071 Rev 1

USO SCREENING

Page 5 of 5

2. Title: Honeywe11 Modular Automation System Acceptance Test Procedure.

USQE \#1

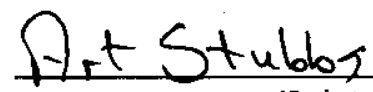

(Print Name)
USQE \#2

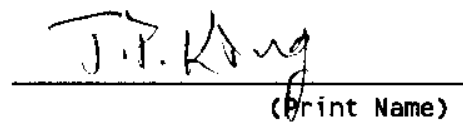

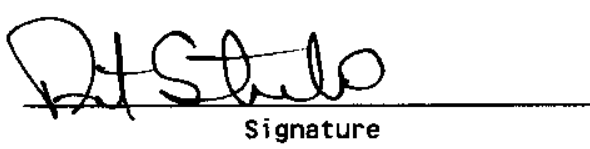

Date:
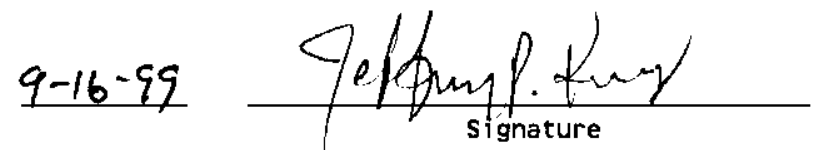

Date:

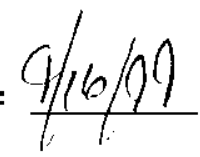

If there is a YES/MAYBE response to questions 1, 2, 3, or 4, then a USO Evaluation must be completed.

The following guidance should be considered when completing this screening. This guidance should not be considered allinclusive; additional factors may need to be considered depending on the nature of the proposed change.

Does the proposed change:

Modify, add, or delete a safety class function of a structure, system or component stated in the authorization basis? Alter the design of a structure, system or component as described in the authorization basis?

Modify, add, or delete the description of operation, operating environment, or analyses of any system or component described in the authorization basis?

Modify, add, delete or conflict with any of the design bases stated in the authorization basis?

Conflict with the principle or general design criteria stated in the authorization basis?

Modify, add, or delete any plant design features described in the authorization basis?

Modify, add, or delete a flow diagram or facility drawing provided in the authorization basis?

Create the potential for new system or component interactions (e.g., seismic, electrical breaker coordination)? 


\title{
Honeywe11 Modular Automation System Acceptance Test Procedure
}

\author{
A. M. Stubbs and L.T. Cunningham
}

Babcock \& Wi lcock Co. , and. WA 99352

U.S. Department of Energy Contract DE-AC06-96RL13200

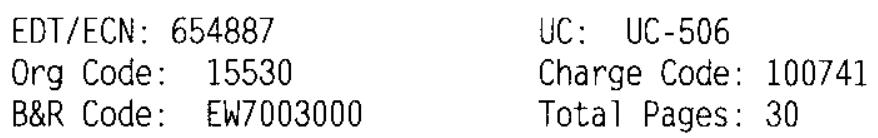

Key Words: Honeywe11. Modular Automation System. MAS. Thermal Stabilization. Acceptance Test

Abstract: This document provides instruction for the acceptance testing of the control system for the 3 new stabilization furnaces being installed in HA-21I and ancillary equipment

Honeywell is a registered trademark of Honeywell Inc., Minneapolis, MN.

Fluke is a registered trademark of Fluke Corporation. Everett. WA.

Transmation. Minitemp, and Flexitester are registered trademarks of Transmation Inc., Rochester. NY.

TRADEMARK DISCLAIMER. Reference herein to any specific commercial product, process. or service by trade name, trademark, manufacturer, or otherwise, does not necessarily constitute or imply its endorsenent. recommendation, or favoring by the United States Government or any agency thereof or its contractors or subcontractors.

Printed in the United States of America. To obtain copies of this document, contact: WHC/BCS Document Control Services, P.0. Box 1970. Mailstop H6-08, Richland WA 99352 Phone (5n9) 372-2420. Eax (5n9) 376-AORg
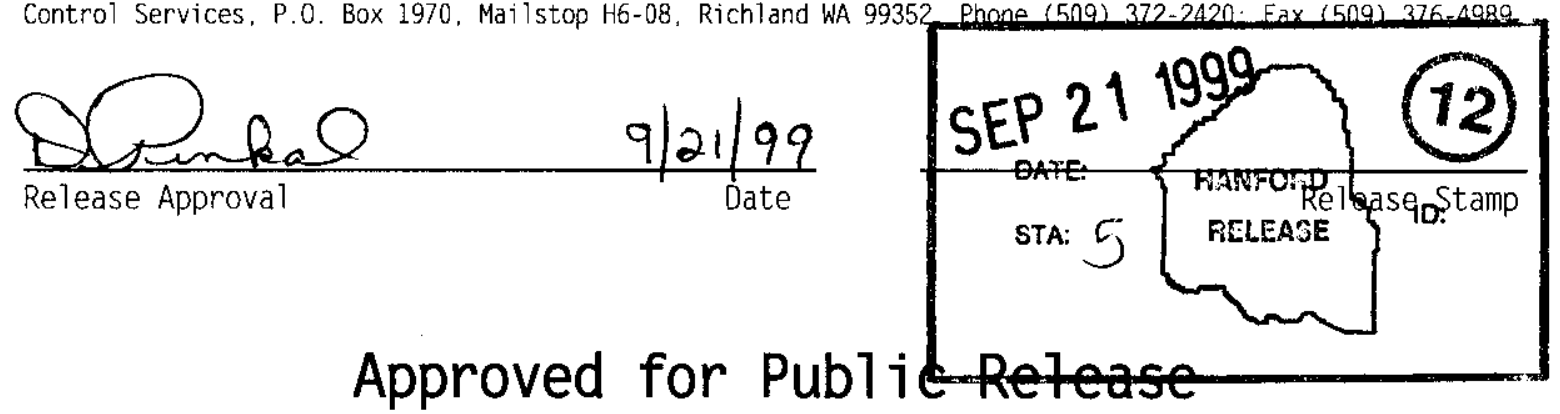


\section{RECORD OF REVISION}

(1) Document Number

Page 1

(2) Title

Honeywell Modular Automation System Acceptance Test Procedure

Change Control Record

(3) Revision

(7)

1

In

Go Ans y-21-99

Revision of ATP that involves the testing of only

the HA-2lI furnaces. Scope of furnace

installation projects has changed and eliminated

the furnace installation in HA-20MB. Address

changes of the discrete input and output cards

included in this revision. ECN 631015

2 RS Deleted HA-20MB from ATP, with ECN 654887
Authorized for Release

\begin{tabular}{l|ll}
\hline (5) Cog. Engr. & (6) Cog. Mgr. Date
\end{tabular} 


\begin{tabular}{|c|c|c|}
\hline $\begin{array}{l}\text { ACCEPTANCE TEST } \\
\text { PROCEDURE }\end{array}$ & $\begin{array}{l}\text { HONEYWELL MOOULAR AUTOMATION } \\
\text { SYSTEM }\end{array}$ & $\begin{array}{l}\text { HNF-SD-CP-ATP-071 } \\
\text { REV-2 } \\
\text { PAGE } 2 \text { OF } 29\end{array}$ \\
\hline
\end{tabular}

TABLE OF CONTENTS

1.0 PURPOSE . . . . . . . . . . . . . . . . . . . . . . . 3

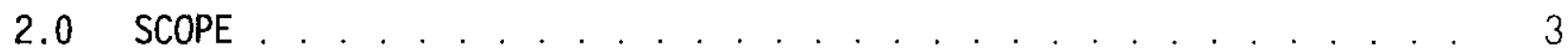

3.0 REFERENCES . . . . . . . . . . . . . . . . . . . 3

4.0 RESPONSIBILITIES . . . . . . . . . . . . . . . . . 3

5.0 SYSTEM DESCRIPTION . . . . . . . . . . . . . . . . . . . . . . . . . 5

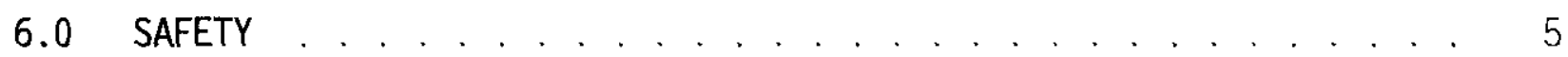

7.0 TEST CONDITIONS AND EQUIPMENT REQUIRED . . . . . . . . . . . . 6

8.0 PROCEDURE . . . . . . . . . . . . . . . . . . . . . . 7

Thermocouple Input Checks . . . . . . . . . . . . . . . . . . . . . 7

Check Analog Output for SCR . . . . . . . . . . . . . . . . 8

Interlock Validation . . . . . . . . . . . . . . . . . . . . . . . 10

Check Digital Signals for Off-Gas Fans . . . . . . . . . . . . . . 14

9.0 EXCEPTIONS LIST . . . . . . . . . . . . . . . . . . . . . . . . . . . . . 16

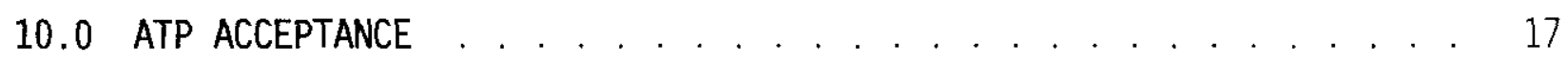

APPENDIX A . . . . . . . . . . . . . . . . . . . . 18

Figure 1 - Honeywe11 Modular Automation System (MAS) . . . . . . . 19

Figure 2 - Digital Input Test Box . . . . . . . . . . . . . . . 20

Figure 3 - Analog Input Module Connection Schematic . . . . . . . . 21

Figure 4 - Analog Output Module Connection Schematic . . . . . . . 22

Figure 5 - Digital Input Module Connection Schematic . . . . . . . 23

Figure 6 - Digital Output Module Connection Schematic . . . . . . . 24

APPENDIX B . . . . . . . . . . . . . . . . . . 25

Data Sheet 1 - HA-21I Temperature Inputs . . . . . . . . . 26

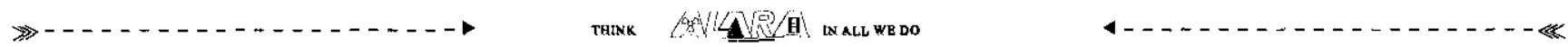




\begin{tabular}{|l|l|l||}
\hline ACCEPTANCE TEST & HONEYWELL MODULAR AUTOMATION & HNF-SD-CP-ATP-071 \\
PROCEDURE & SYSTEM & REV-2 \\
& & \\
& & \\
\hline
\end{tabular}

\subsection{PURPOSE}

The purpose of this Acceptance Test Procedure (ATP) is to verify the operability of the three new furnaces as controlled by the new Honeywe l] Modular Automation System (MAS). The Honeywell MAS is being installed in the PFP to control the three thermal stabilization furnaces in glovebox HA-21I.

\section{$2.0 \quad$ SCOPE}

This ATP provides instructions for testing the configuration of the Honeywe11 MAS at the Plutonium Finishing Plant (PFP). The test wi11 be a field test of the analog inputs, analog outputs, and software interlocks. The interlock test will check the digital input and outputs. Field equipment will not be connected for this test. Simulated signals will be used for thermocouple and limit switch inputs. An Operational Test Procedure (OTP) will be written to perform field testing once the MAS and furnaces have been installed.

\subsection{REFERENCES}

WHC-IP-1026, Engineering Practice Guide7ines, Appendix M

\subsection{RESPONSIBILITIES}

\section{Test Director}

The test director will be selected from the PFP Process Engineering Group: The Test Director sha11:

- Coordinate and direct acceptance testing.

- Confirm that all prestart requirements have been met before allowing the test to begin.

- If needed, alter the test sequence after verifying that there is no adverse impact.

- Ensure that the system is left in a safe mode if the test is to be suspended for a period of time. 


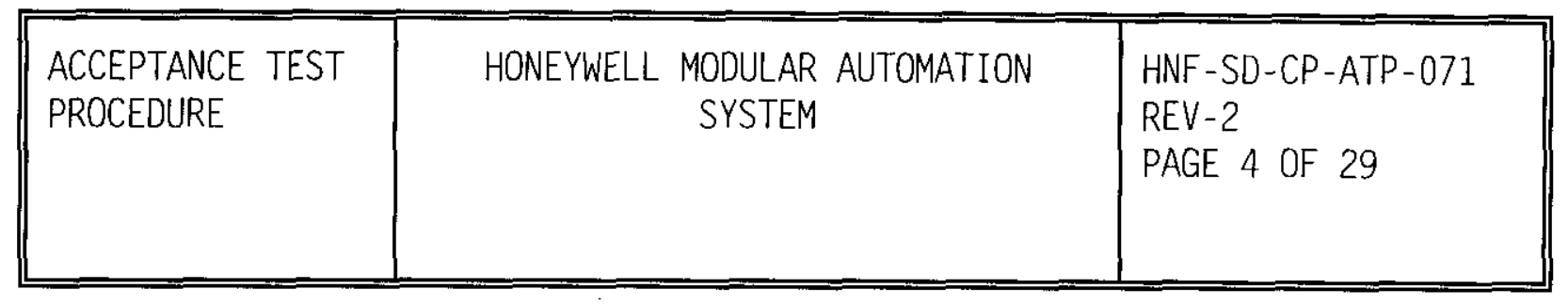

- Reverify test prerequisites before restarting a suspended test.

- Initial each step in the test procedure as it is performed.

- Evaluate the need to make changes to the test and initiate ECNs to document those changes.

- Review and approve test data sheets and exceptions.

- Approve resolution to test exceptions.

\section{Witnesses}

A test witness shal1 be provided by Quality Assurance. Test witnesses sha]1:

- Witness all or selected portions of the test.

- Review and approve test data sheets and exceptions for the sections of the test that they witness.

- Approve resolution to test exceptions for the sections of the test that they witness.

\section{Test Performer}

The person performing the test shall be designated by the test director. The performer shall:

- Perform the test under the direction of the test director.

- Record required information on the test data sheets as well as initial and date the form.

\subsection{SYSTEM DESCRIPTION}

The thermal stabilization furnaces will be used to stabilize plutonium bearing materials at the PFP for long term storage. Three new furnaces located in glovebox HA-21I will be connected to a Honeywell MAS (see Figure 1). The control configuration of the Honeywel1 MAS provides temperature control to heat the furnaces to $1000^{\circ} \mathrm{C}$ and hold for a prescribed duration depending on the type of material being heated in the furnace. Analog input signals being processed by the MAS include: furnace control temperature, furnace high alarm temperature, furnace 


\begin{tabular}{||l|r|l|}
\hline $\begin{array}{l}\text { ACCEPTANCE TEST } \\
\text { PROCEDURE }\end{array}$ & HONEYWELL MODULAR AUTOMATION \\
& SYSTEM & $\begin{array}{l}\text { HNF-SD-CP-ATP-071 } \\
\text { REV-2 } \\
\text { PAGE 5 OF } 29\end{array}$ \\
& \\
\hline
\end{tabular}

off-gas temperature, and glovebox temperature. Analog output signals are sent to the Silicon Control Rectifier (SCR) to supply power to the furnaces. Digital inputs include the furnace door limit switches and a power signal from the off-gas fans. Digital outputs include relay power from the furnace interlock logic and the off-gas fan start/stop signal.

\subsection{SAFETY}

A pre-job safety meeting shal1 be conducted in accordance with Plutonium Operation Administration Manua 7. HNF-IP-0821, Chapter 12, Section 5.12 and meeting attendance sha11 be documented in Table 1 by Process Engineering prior to work start. This ATP shall be read and discussed in detail by all personnel involved with its performance.

\begin{tabular}{|c|c|c|c|}
\hline \multicolumn{4}{|c|}{$\begin{array}{c}\text { TABLE } 1 \\
\text { PRE-JOB SAFETY/OPERABILITY BRIEFING LIST }\end{array}$} \\
\hline \multicolumn{2}{|c|}{ PRESENTER: } & \multicolumn{2}{|l|}{ DATE: } \\
\hline ATTENDEES & ORGANIZATION & ATTENDEES & ORGANIZATION \\
\hline & & & \\
\hline & & & \\
\hline & & & \\
\hline & & & \\
\hline & & & \\
\hline & & & \\
\hline & & & \\
\hline & & & \\
\hline
\end{tabular}




\begin{tabular}{||l|r|l||}
\hline ACCEPTANCE TEST & HONEYWELL MODULAR AUTOMATION & HNF-SD-CP-ATP-071 \\
PROCEDURE & SYSTEM -2 \\
& & PAGE 6 OF 29 \\
& & \\
\hline
\end{tabular}

\subsection{TEST CONDITIONS AND EQUIPMENT REQUIRED}

The control configuration acceptance test will be performed in room 230A and $235 \mathrm{~B}$ in the PFP complex. The personal computer (PC) will be connected to the Honeywe11 MAS with a coaxial cable. The 50-ohm terminating resistors wi11 be in place. Leads maybe 1 ifted or blocks replaced with electrical/thermocouple connections as needed during performance of this ATP.

A special test box will be used to test the function of the $115 \mathrm{~V}$ discreet inputs (see Figure 2). The box contains four separate test points. Each point has its own switch and removable cable. The cable is connected to the address point and the common (B1, B2, or B3). To turn on the input, the switch is closed, and to turn it off, the switch is opened. To prevent electric shock, any unused electric cables must be disconnected from the box. In addition, the cable must be disconnected from the box whenever connecting or disconnecting from the digital input card.

Current measurement and continuity checks wi11 be taken with a FLUKE 8060A:

Device ID \#

Last Calibrated

Next Calibration

For Type $K$ thermocouple signal generation, either of the following instruments can be utilized:

Calibrated Transmation PPS minitemp Calibrator, Model 1064P

Device ID \# Last Calibrated

$O R$ Next Calibration

Calibrated Transmation PPS Flexitester, Mode1 1080

Device ID \# Last Calibrated Next Calibration 


\begin{tabular}{|l|l|l||}
\hline ACCEPTANCE TEST & HONEYWELL MODULAR AUTOMATION & HNF-SD-CP-ATP-071 \\
PROCEDURE & RYSTEM 2 \\
& & PAGE 7 OF 29 \\
& & \\
\hline
\end{tabular}

\subsection{PROCEDURE}

Discrepancies will be noted on the Exceptions List provided (Section 8.0) and according to provisions outlined in WHC-IP-1026. Engineering Practice Guidelines, Appendix M.

8.1 Download the current controller configuration to the logic controller.

8.2 Enter VIEW from the windows screen and acknowledge all alarms.

Thermocouple Input Checks (see Figure 3)

8.3 From the FURNACE 21I-1 screen, test the following temperature inputs for FUR-21I-1.

8.3.1 Input compensated temperature inputs to Address 32 per data sheet 1 to check temperature controller thermocouple input.

8.3.2 Input compensated temperature inputs to Address 33 per data sheet 1 to check furnace high temperature alarm thermocouple input.

8.3.3 Input compensated temperature inputs to Address 41 per data sheet 1 to check off-gas thermocouple input.

8.4 From the FURNACE 21I-2 screen, test the following temperature inputs for FUR-21I-2.

8.4.1 Input compensated temperature inputs to Address 34 per data sheet 1 to check temperature controller thermocouple input.

8.4.2 Input compensated temperature inputs to Address 35 per data sheet 1 to check furnace high temperature alarm thermocouple input. 


\begin{tabular}{|l|r|l|}
\hline ACCEPTANCE TEST & HONEYWELL MODULAR AUTOMATION & HNF-SD-CP-ATP-071 \\
PROCEDURE & SYSTEM & REV-2 \\
& & \\
& & \\
\hline
\end{tabular}

8.4.3 Input compensated temperature inputs to Address 42 per data sheet 1 to check off-gas thermocouple input

8.5 From the FURNACE 21I-3 screen, test the following temperature inputs for FUR-21I-3.

8.5.1 Input compensated temperature inputs to Address 36 per data sheet 1 to check temperature controller thermocouple input.

8.5.2 Input compensated temperature inputs to Address 37 per data sheet 1 to check furnace high temperature alarm thermocouple input.

8.5.3 Input compensated temperature inputs to Address 43 per data sheet 1 to check off-gas thermocouple input.

8.6 From the FURNACE OVERVIEW screen, test the following temperature inputs for glovebox HA-21I.

8.6.1 Connect blank test thermocouples to Addresses 39 and 40 . Input compensated temperature inputs to Address 38 per data sheet 1 to glovebox thermocouple input.

8.6.2 Connect blank test thermocouples to Addresses 38 and 40 . Input compensated temperature inputs to Address 39 per data sheet 1 to glovebox thermocouple input.

8.6.3 Connect blank test thermocouples to Addresses 38 and 39 . Input compensated temperature inputs to Address 40 per data sheet 1 to glovebox thermocouple input.

Check Analog Output for SCR (see Figure 4)

8.7 Record the output of address 72 when Output for furnace 21I-1 is $0 \%$ as seen on the FURNACE 21I-1 screen. mA. 


\begin{tabular}{|l|l|l||}
\hline ACCEPTANCE TEST & \multicolumn{1}{|c|}{ HONEYWELL MODULAR AUTOMATION } & HNF-SD-CP-ATP-071 \\
PROCEDURE & SYSTEM & PEV-2 9 OF 29 \\
& & \\
\hline
\end{tabular}

8.8 From FURNACE 21I-1 screen, start heating cycle by pressing the 1-OXIDE button.

8.9 Monitor output of address 72. Output sha11 be in $4-20 \mathrm{~mA} \pm 0.1 \mathrm{~mA}$ range and should increase as the setpoint climbs.

8.10 Record output for address 72 when Output for furnace 21 I- 1 is $100 \%$ as seen on the FURNACE 21I-1 screen. $\mathrm{mA}$

8.11 Stop heating cycle by pressing Stop Cycle button.

8.12 Record the output of address 73 when Output for furnace 21I-2 is $0 \%$ as seen on the FURNACE $21 \mathrm{I}-2$ screen. mA

8.13 From FURNACE 21I-2 screen, start heating cycle by pressing the 1-OXIDE button.

8.14 Monitor output of address 73. Output sha11 be in $4-20 \mathrm{~mA} \pm 0.1 \mathrm{~mA}$ range and should increase as the setpoint climbs.

8.15 Record output for address 73 when Output for furnace $21 \mathrm{I}-2$ is $100 \%$ as seen on the FURNACE $21 \mathrm{I}-2$ screen. $\mathrm{mA}$

8.16 Stop heating cycle by pressing Stop Cycle button.

8.17 Record the output of address 74 when Output for furnace 21I-3 is $0 \%$ as seen on the FURNACE $211-3$ screen. $\mathrm{mA}$

8.18 From FURNACE 21I-3 screen, start heating cycle by pressing the 1-OXIDE button.

8.19 Monitor output of address 74 . Output shal1 be in $4-20 \mathrm{~mA} \pm 0.1 \mathrm{~mA}$ range and should increase as the setpoint climbs.

8.20 Record output for address 74 when Output for furnace $21 \mathrm{I}-3$ is $100 \%$ as seen on the FURNACE 21I-3 screen. $\mathrm{mA}$ 


\begin{tabular}{|c|c|c|}
\hline $\begin{array}{l}\text { ACCEPTANCE TEST } \\
\text { PROCEDURE }\end{array}$ & $\begin{array}{c}\text { HONEYWELL MODULAR AUTOMATION } \\
\text { SYSTEM }\end{array}$ & $\begin{array}{l}\text { HNF-SD-CP-ATP-071 } \\
\text { REV-2 } \\
\text { PAGE } 10 \text { OF } 29\end{array}$ \\
\hline
\end{tabular}

8.21 Stop heating cycle by pressing Stop Cycle button.

\section{Interlock Validation}

8.22 On the Digital Input card 621-1160R, ensure the jumpers are connected across contact points B1, B2, and B3 and contact points T1, T2, and T3. (see Figure 5)

8.23 On the Digital Output card 621-2150R, ensure the jumpers are connected across contact points B1, B2, and B3 and contact points $\mathrm{T} 1, \mathrm{~T} 2$, and $\mathrm{T} 3$. (see Figure 6 )

8.24 Insta11 test thermocouples to addresses $32-43$ on the UAIs.

8.25 On the FURNACE OVERVIEW screen, ensure EMERGENCY SHUTDOWN button is RED. Push EMERGENCY SHUTDOWN button if gray.

8.26 Connect Digital input test box to input addresses 80,81 , and 82 . The common (-) is to be connected to B1/B2/B3.

8.27 Close contacts 80, 81, and 82. The furnace doors should be closed on FURNACE OVERVIEW screen for FUR-21I-1, FUR-21I-2, FUR-21I-3.

8.28 Perform Furnace FUR-21I-1 interlock validation.

8.28.1 From FURNACE 21I-1 screen, start heating cycle by pressing the 1-OXIDE button.

8.28.2 Verify continuity for address 96 on the DI card.

8.28.3 Open contact 80 with DI test box.

8.28.4 Verify open circuit for address 96 .

8.28.5 Verify door to furnace FUR-21I-1 opens.

8.28.6 Close contact 80 with DI test box. 


\begin{tabular}{||l|c|l||}
\hline \hline ACCEPTANCE TEST & HONEYWELL MODULAR AUTOMATION \\
PROCEDURE & SYSTEM & HNF-SD-CP-ATP-071 \\
& REV-2 \\
& PAGE 11 OF 29 \\
\hline
\end{tabular}

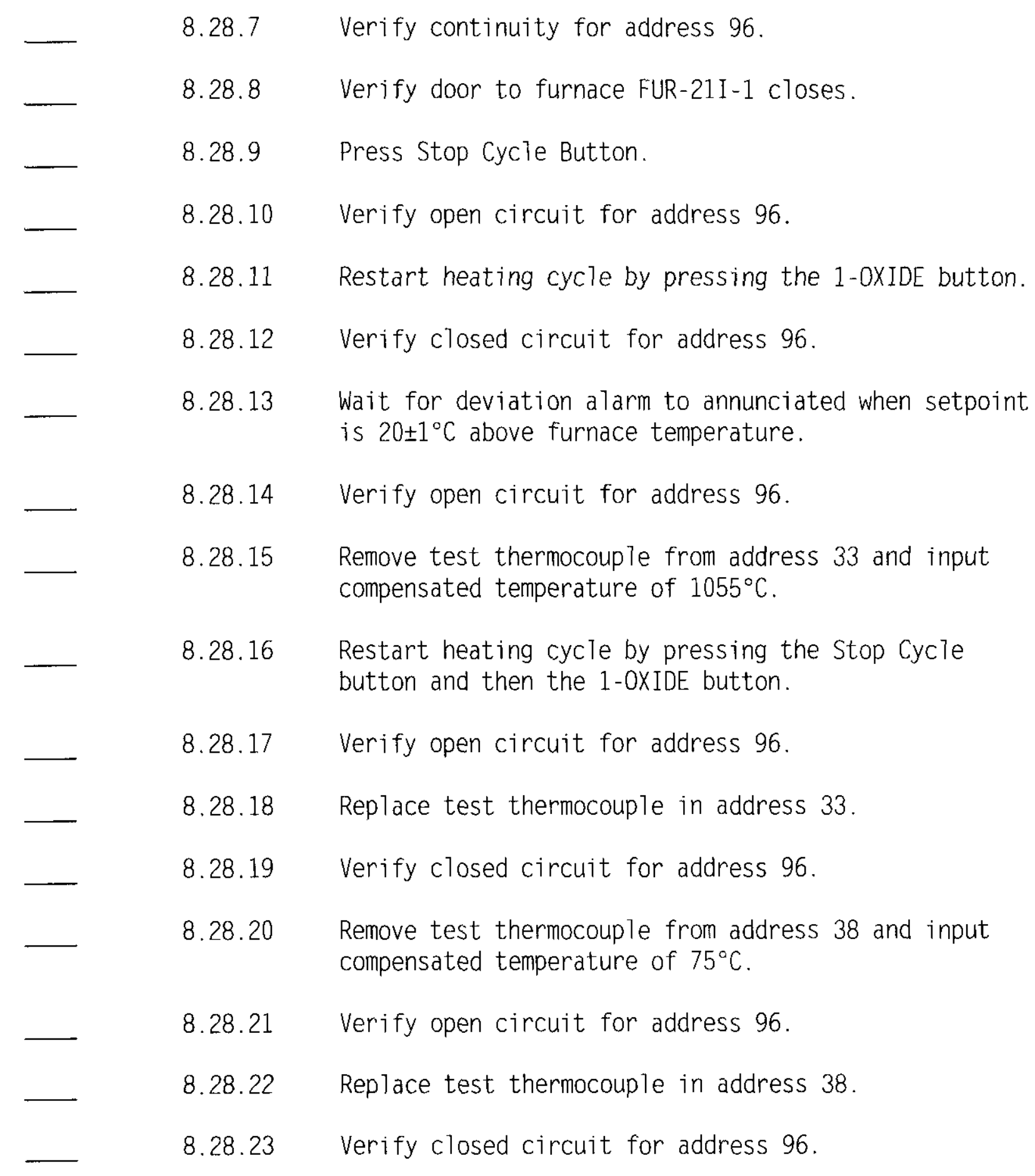




\begin{tabular}{|l|r|l||}
\hline $\begin{array}{l}\text { ACCEPTANCE TEST } \\
\text { PROCEDURE }\end{array}$ & HONEYWELL MODULAR AUTOMATION \\
& & $\begin{array}{l}\text { HNF-SD-CP-ATP-071 } \\
\text { SYSTEM -2 } \\
\text { PAGE 12 OF 29 }\end{array}$ \\
& & \\
\hline
\end{tabular}

8.28.24 Press Emergency Stop Button.

8.28.25 Verify open circuit for address 96.

8.29 Perform Furnace FUR-21I-2 interlock validation.

8.29.1 From FURNACE 21I-2 screen, start heating cycle by pressing the 1-OXIDE button.

8.29.2 Verify continuity for address 97 on the DI card.

8.29.3 Open contact 81 with DI test box.

8.29.4 Verify open circuit for address 97.

8.29.5 Verify door to furnace FUR-21I-2 opens.

8.29.6 Close contact 81 with DI test box.

8.29.7 Verify continuity for address 97

8.29.8 Verify door to furnace FUR-21I-2 closes.

8.29.9 Press Stop Cycle Button.

8.29.10 Verify open circuit for address 97.

8.29.11 Restart heating cycle by pressing the 1-OXIDE button.

8.29.12 Verify closed circuit for address 97.

8.29.13 Wait for deviation alarm to annunciated when setpoint is $20 \pm 1^{\circ} \mathrm{C}$ above furnace temperature.

8.29.14 Verify open circuit for address 97. 


\begin{tabular}{|l|c|l||}
\hline ACCEPTANCE TEST & HONEYWELL MODULAR AUTOMATION \\
PROCEDURE & SYSTEM & HNF-SD-CP-ATP-071 \\
& & REV-2 \\
& PAGE 13 OF 29 \\
& \\
\hline
\end{tabular}

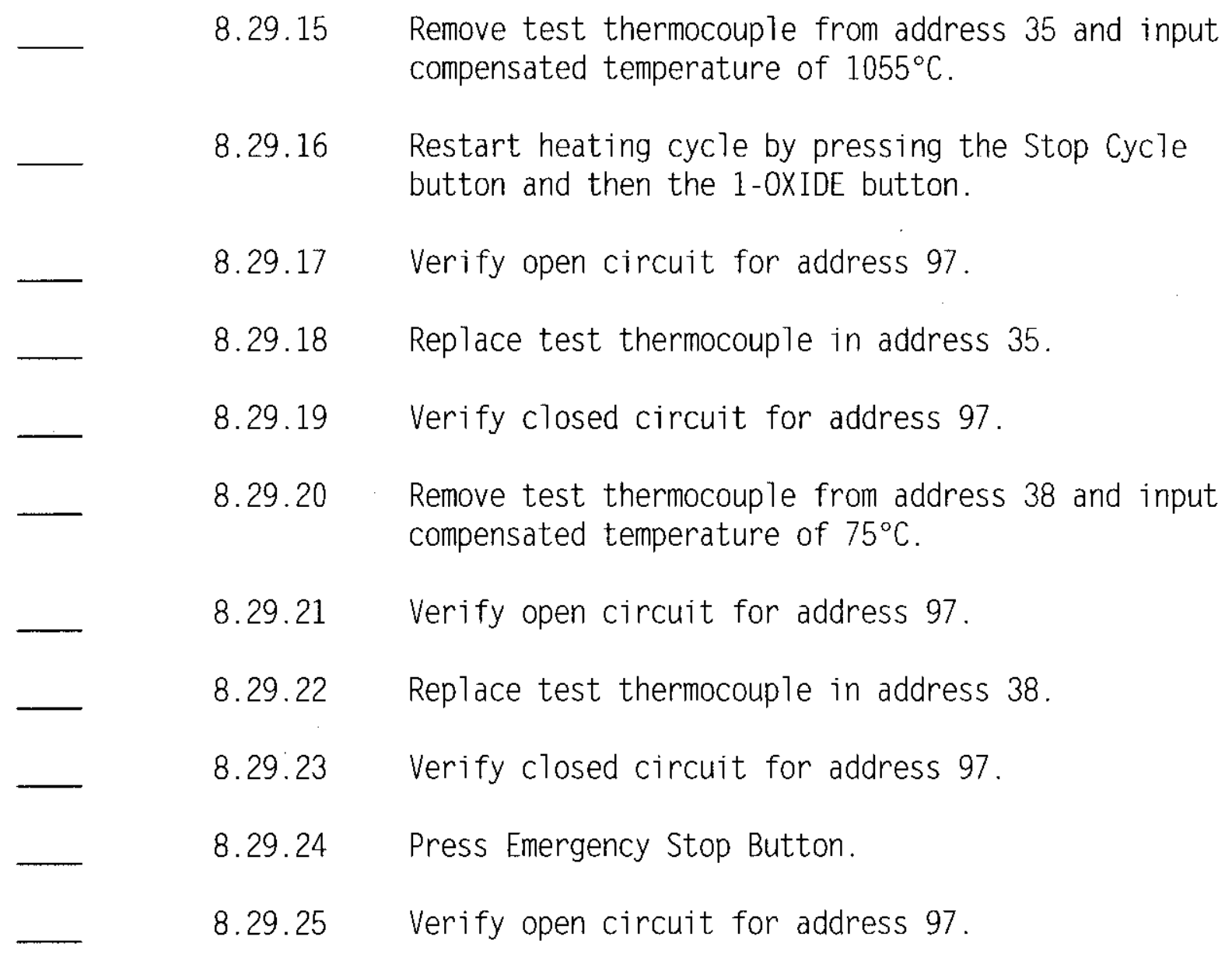

8.30 Perform Furnace FUR-21I-3 interlock validation.

$\begin{array}{cl}8.30 .1 & \begin{array}{l}\text { From FURNACE 21I-3 screen, start heating cycle by } \\ \text { pressing the 1-OXIDE button. }\end{array} \\ \text { 8.30.2 } & \text { Verify continuity for address } 98 \text { on the DI card. } \\ 8.30 .3 & \text { Open contact } 82 \text { with DI test box. } \\ 8.30 .4 & \text { Verify open circuit for address } 98 .\end{array}$




\begin{tabular}{||l|c|l||}
\hline ACCEPTANCE TEST & HONEYWELL MODULAR AUTOMATION & HNF-SD-CP-ATP-071 \\
PROCEDURE & SYSTEM & REV-2 \\
& & \\
& & \\
\hline
\end{tabular}

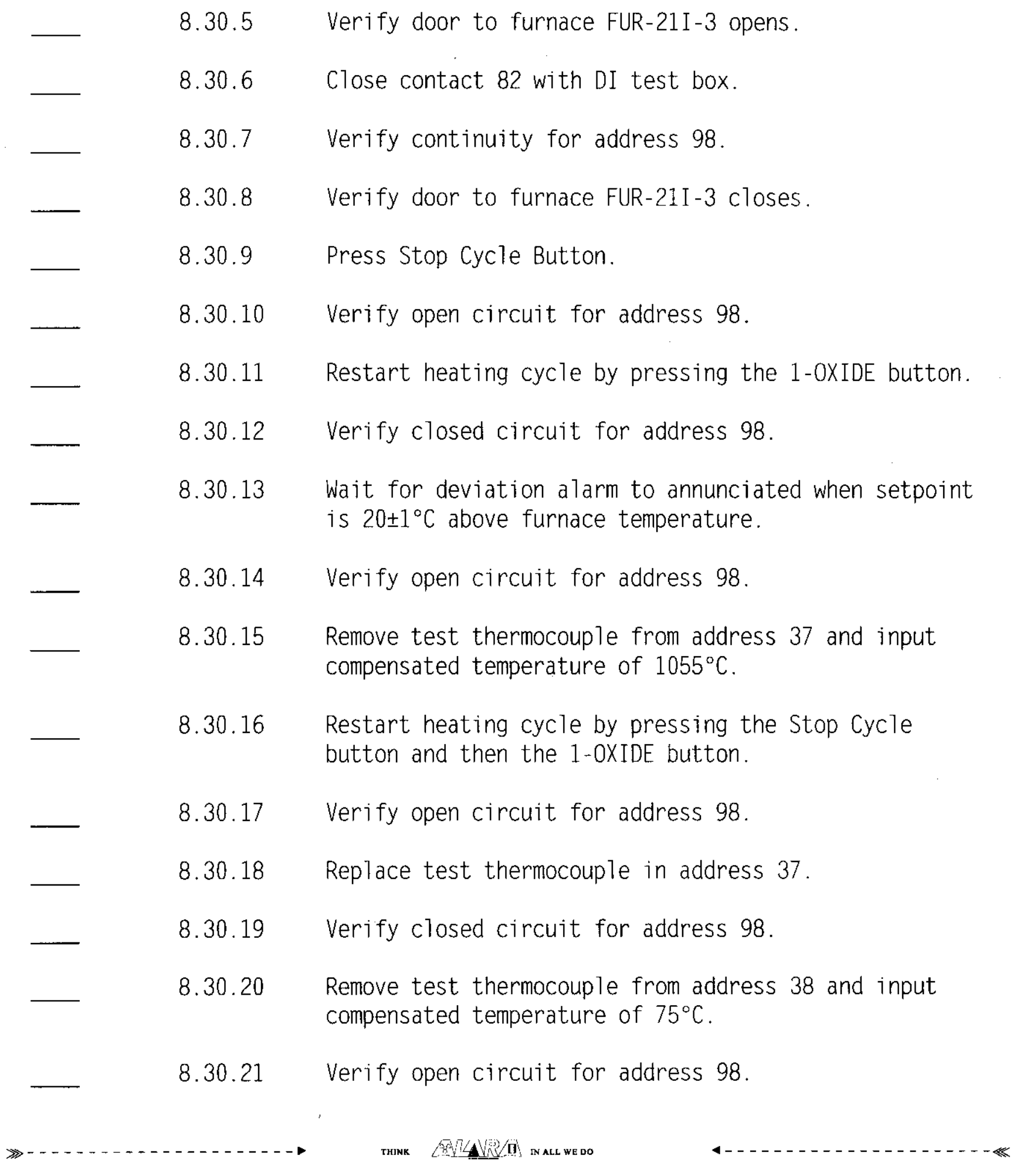




\begin{tabular}{|c|c|c|}
\hline $\begin{array}{l}\text { ACCEPTANCE TEST } \\
\text { PROCEDURE }\end{array}$ & $\begin{array}{c}\text { HONEYWELL MODULAR AUTOMATION } \\
\text { SYSTEM }\end{array}$ & $\begin{array}{l}\text { HNF-SD-CP-ATP- } 071 \\
\text { REV-2 } \\
\text { PAGE } 15 \text { OF } 29\end{array}$ \\
\hline
\end{tabular}

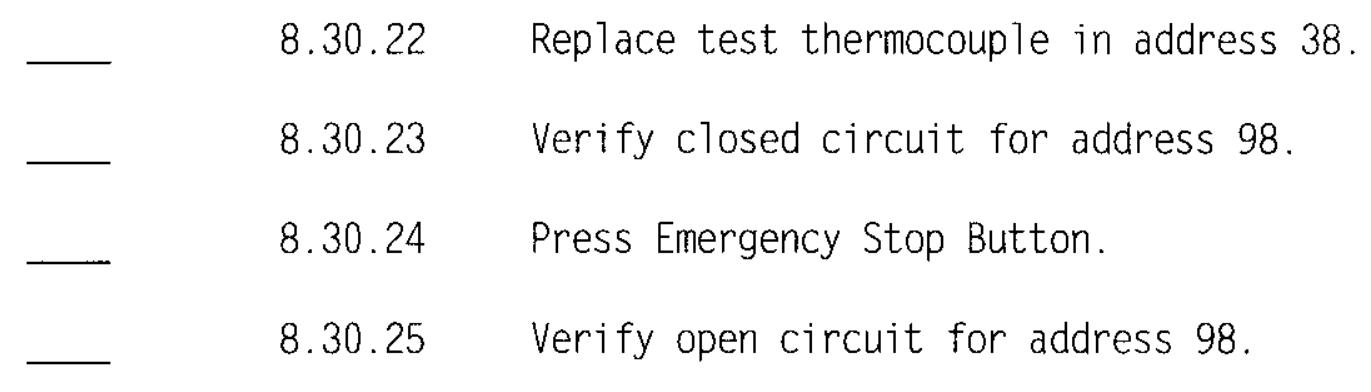

_ 8.31 Disconnect test box from addresses 80,81 , and 82 .

\section{Check Digita] Signals for Off-Gas Fans}

8.32 On the Digital Output card 621-2150R, ensure the jumpers are connected across contact points B1, B2, and B3 and contact points T1, T2, and T3. (see Figure 6)

8.33 From the OFF-GAS FAN screen, press Vacuum Fan 1 button to close contact. Motor and part of line going through the motor should turn RED.

8.34 Verify continuity between contact 4 (address 99) and B1/B2/B3 on the digital input card.

8.35 From the OFF-GAS FAN screen, press Vacuum Fan 1 button to open contact. Motor and part of line going through the motor should turn black.

8.36 Verify open circuit between contact 4 (address 99) and B1/B2 on the digital input card.

8.37 From the OFF-GAS FAN screen, press Vacuum Fan 2 button to close contact. Motor and part of line going through the motor should turn RED.

8.38 Verify continuity between contact 5 (address 100) and B1/B2/B3 on the digital input card. 


\begin{tabular}{||l|l|l||}
\hline ACCEPTANCE TEST & HONEYWELL MODULAR AUTOMATION & HNF-SD-CP-ATP-071 \\
PROCEDURE & SYSTEM & PEV -2 \\
& & \\
& & \\
\hline
\end{tabular}

8.39 From the OFF-GAS FAN screen, press Vacuum Fan 2 button to open contact. Motor and part of 1 ine going through the motor should turn black.

8.40 Verify open circuit between contact 5 (address 100) and B1/B2/B3 on the digital input card.

8.41 Connect Digital input test box to input addresses 83 and 84 . The common (-) is to be connected to B1/B2/B3.

8.42 Close circuit to address 83 and verify that the OFF-GAS FAN 1ight on FURNACE OVERVIEW changes to red.

8.43 Open circuit to address 83 and verify that the OFF-GAS FAN 1 ight on FURNACE OVERVIEW changes to white.

8.44 Close circuit to address 84 and verify that the OFF-GAS FAN 1ight on FURNACE OVERVIEW changes to red.

8.45 Open circuit to address 84 and verify that the OFF-GAS FAN 1ight on FURNACE OVERVIEW changes to white.

8.46 Disconnect test box from address 83 and 84 . Disconnect common from $\mathrm{B} 1 / \mathrm{B} 2 / \mathrm{B} 3$.

8.47 Test Engineer and Quality Control will verify configuration of PCL rack per Drawing $\mathrm{H}-2-824345$ Sh 3

Test Engineer

Quality Control 


\begin{tabular}{||l|c|l||}
\hline \hline ACCEPTANCE TEST & HONEYWELL MODULAR AUTOMATION & HNF-SD-CP-ATP-071 \\
PROCEDURE & REV-2 \\
& & PAGE 17 OF 29 \\
& & \\
\hline
\end{tabular}

\subsection{EXCEPTIONS LIST}

\begin{tabular}{|c|c|c|c|}
\hline No. & EXCEPTION & RESOLUTION & SIGNATURE/DATE \\
\hline & & & Test Director \\
\hline & & & Quality Assurance \\
\hline & & & Test Director \\
\hline & & & Qual ity Assurance \\
\hline & & & Test Director \\
\hline & & & Qual ity Assurance \\
\hline & & & Test Director \\
\hline & & & Qual ity Assurance \\
\hline
\end{tabular}




\begin{tabular}{||l|l|l||}
\hline \hline ACCEPTANCE TEST & HONEYWELL MODULAR AUTOMATION & HNF-SD-CP-ATP-071 \\
PROCEDURE & SYSTEM & REV -2 \\
& & \\
& & \\
\hline
\end{tabular}

\subsection{ATP ACCEPTANCE}

Any equipment non-conformance or anomalies will be listed on the Exceptions List.

Upon test completion and acceptance, the Cognizant Engineer wi11 prepare an Acceptance Test Report (ATR) from the original ATP with field entries and transmit it to Central Files via Engineering Data Transmittal (EDT).

The undersigned concur that the ATP was completed successfully. The Honeywe 11 Modular Automation System (MAS) was tested and operates within acceptable parameters.

Quality Engineer

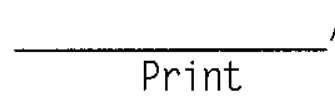

'

Signature

IDate

Cognizant Engineer IDate

Cognizant Engineer Group Manager

$$
\text { Print } \frac{}{\text { Signature }}
$$
/Date

Print $\frac{}{\text { Signature }}$




\begin{tabular}{|l|r|l||}
\hline $\begin{array}{l}\text { ACCEPTANCE TEST } \\
\text { PROCEDURE }\end{array}$ & HONEYWELL MODULAR AUTOMATION \\
& SYSTEM & $\begin{array}{l}\text { HNF-SD-CP-ATP-071 } \\
\text { REV-2 } \\
\text { PAGE 19 OF } 29\end{array}$ \\
& \\
\hline
\end{tabular}

APPENDIX A

FIGURES 


\begin{tabular}{||l|r|l||}
\hline $\begin{array}{l}\text { ACCEPTANCE TEST } \\
\text { PROCEDURE }\end{array}$ & HONEYWELL MODULAR AUTOMATION \\
SYSTEM & $\begin{array}{l}\text { HNF-SD-CP-ATP-071 } \\
\text { REV-2 } \\
\text { PAGE 20 OF } 29\end{array}$ \\
& & \\
\hline
\end{tabular}

Figure 1 - Honeywell Modular Automation System (MAS)

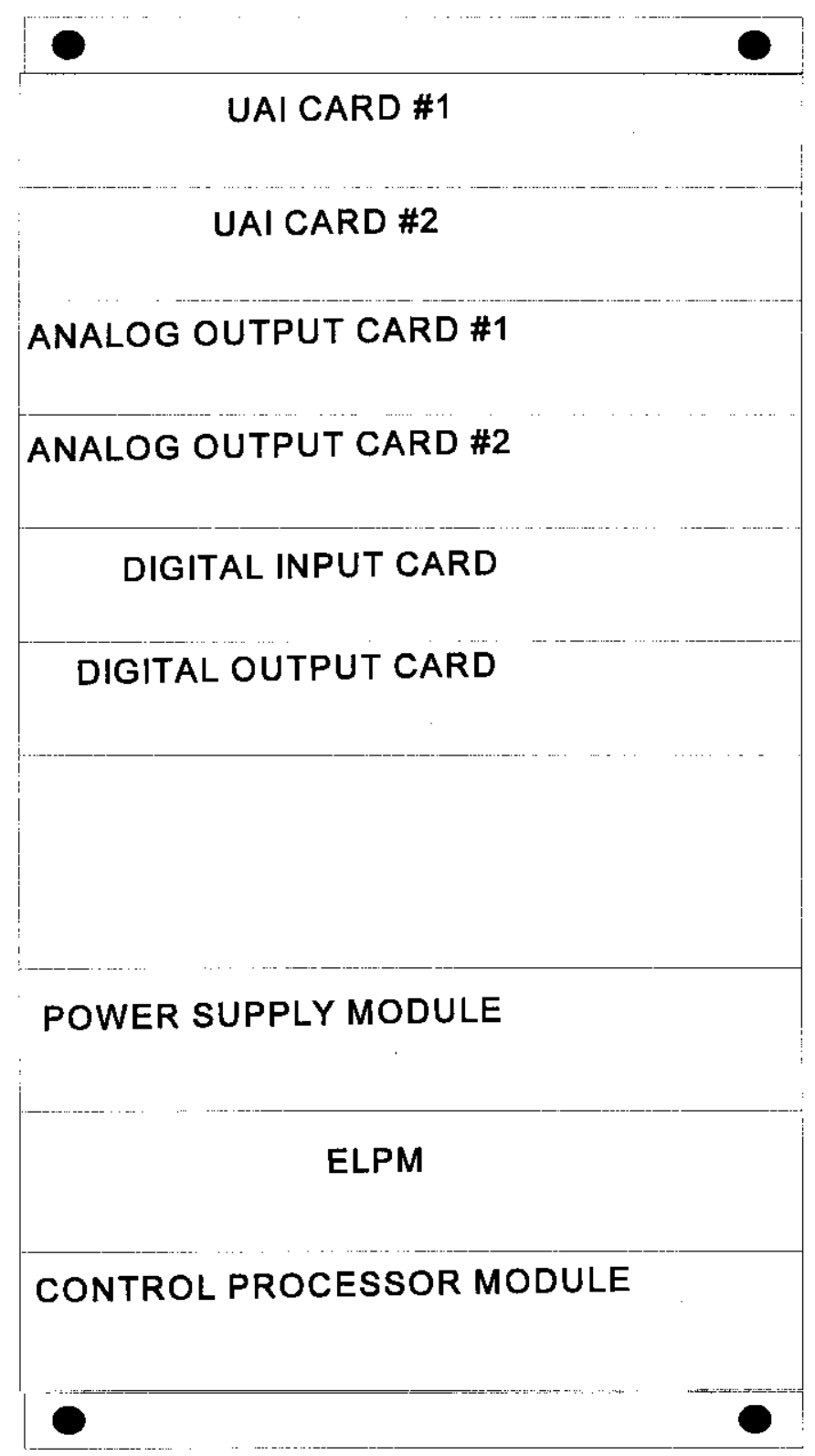




\begin{tabular}{|l|r|l||}
\hline ACCEPTANCE TEST & $\begin{array}{r}\text { HONEYWELL MODULAR AUTOMATION } \\
\text { SYSOCEDURE }\end{array}$ & $\begin{array}{l}\text { HNF-SD-CP-ATP-071 } \\
\text { REV-2 } \\
\text { PAGE 21 OF } 29\end{array}$ \\
& & \\
\hline
\end{tabular}

Figure 2 - Digital Input Test Box
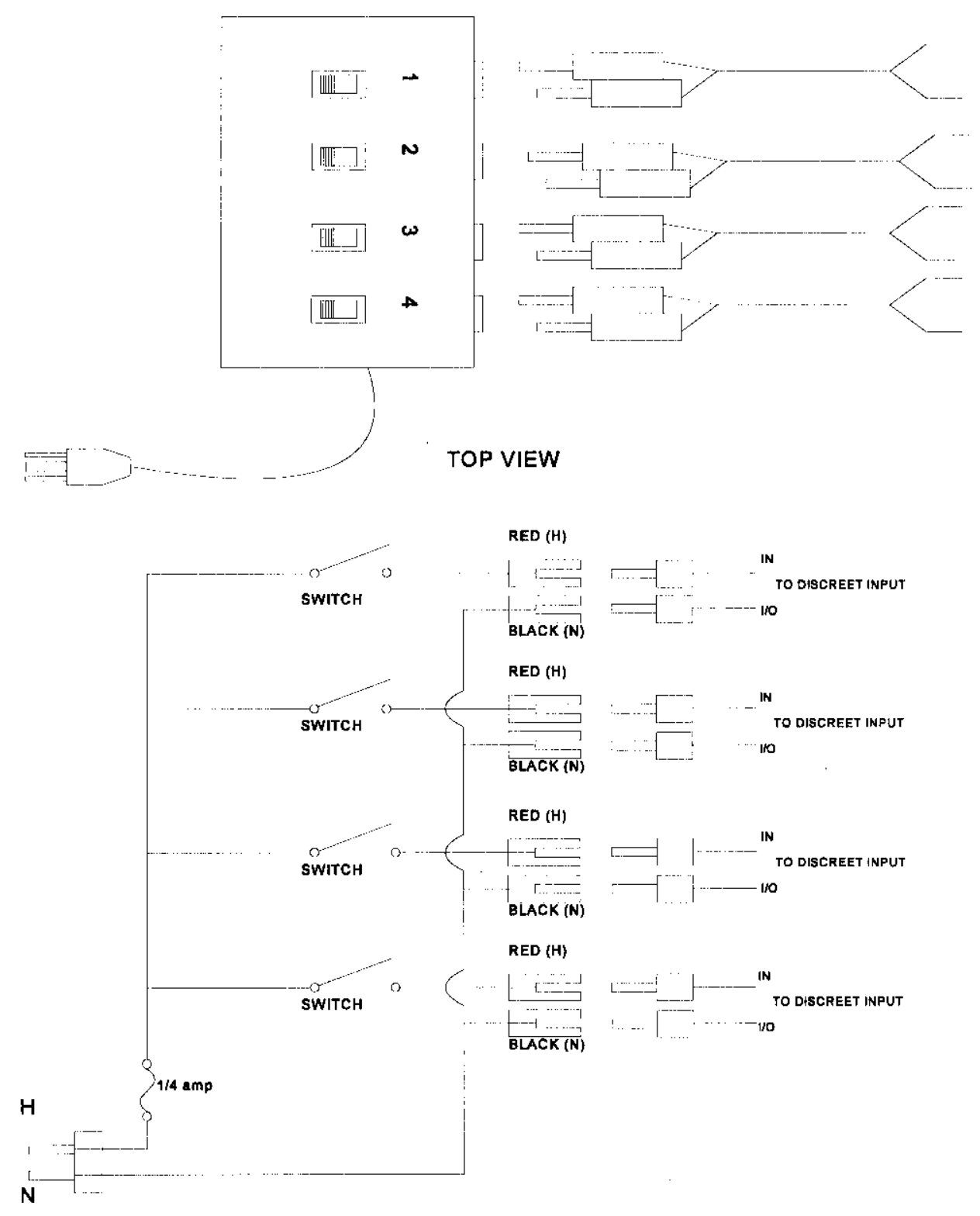


\begin{tabular}{|c|c|c|}
\hline $\begin{array}{l}\text { ACCEPTANCE TEST } \\
\text { PROCEDURE }\end{array}$ & $\begin{array}{l}\text { HONEYWELL MODULAR AUTOMATION } \\
\text { SYSTEM }\end{array}$ & $\begin{array}{l}\text { HNF-SD-CP-ATP-071 } \\
\text { REV-2 } \\
\text { PAGE } 22 \text { OF } 29\end{array}$ \\
\hline
\end{tabular}

Figure 3 - Analog Input Module Connection Schematic

\begin{tabular}{|c|c|}
\hline CARD \#1 & CARD \#2 \\
\hline ADDRESS & ADDRESS \\
\hline 0 & 32 \\
\hline 1 & 33 \\
\hline 2 & 34 \\
\hline 3 & 35 \\
\hline 4 & 36 \\
\hline 5 & 37 \\
\hline 6 & 38 \\
\hline 7 & 39 \\
\hline B & 40 \\
\hline 9 & 41 \\
\hline 10 & 42 \\
\hline 11 & 43 \\
\hline 12 & 44 \\
\hline 13 & 45 \\
\hline 14 & 46 \\
\hline 15 & 47 \\
\hline
\end{tabular}

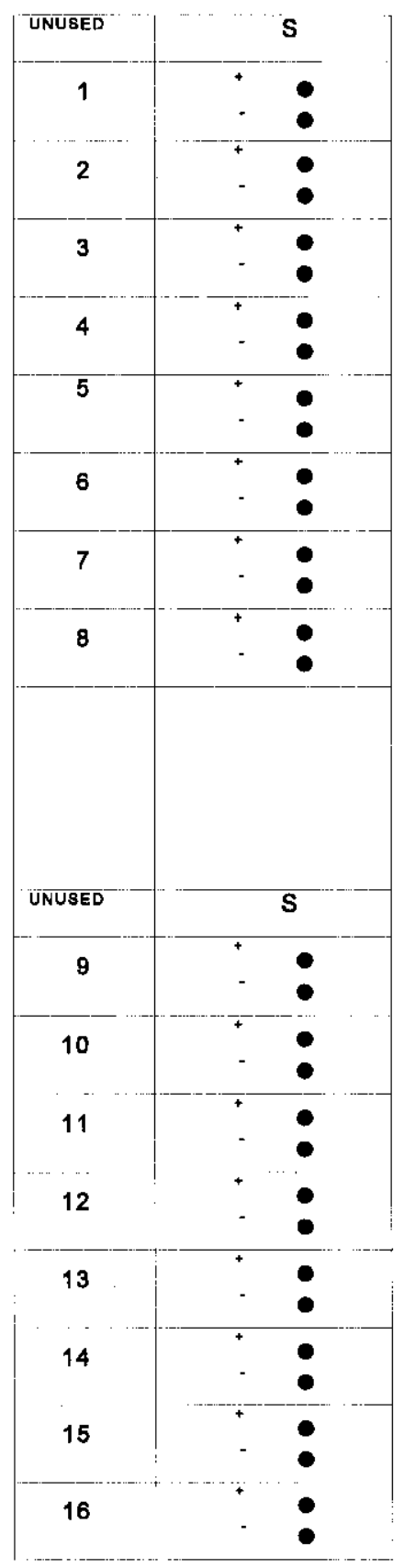




\begin{tabular}{||l|r|l||}
\hline $\begin{array}{l}\text { ACCEPTANCE TEST } \\
\text { PROCEDURE }\end{array}$ & HONEYWELL MODULAR AUTOMATION \\
SYSTEM & $\begin{array}{l}\text { HNF-SD-CP-ATP-071 } \\
\text { REV-2 } \\
\text { PAGE 23 OF 29 }\end{array}$ \\
& & \\
\hline
\end{tabular}

Figure 4 - Analog Output Module Connection Schematic

CARD \#1 CARD \#2

ADDRESS ADDRESS

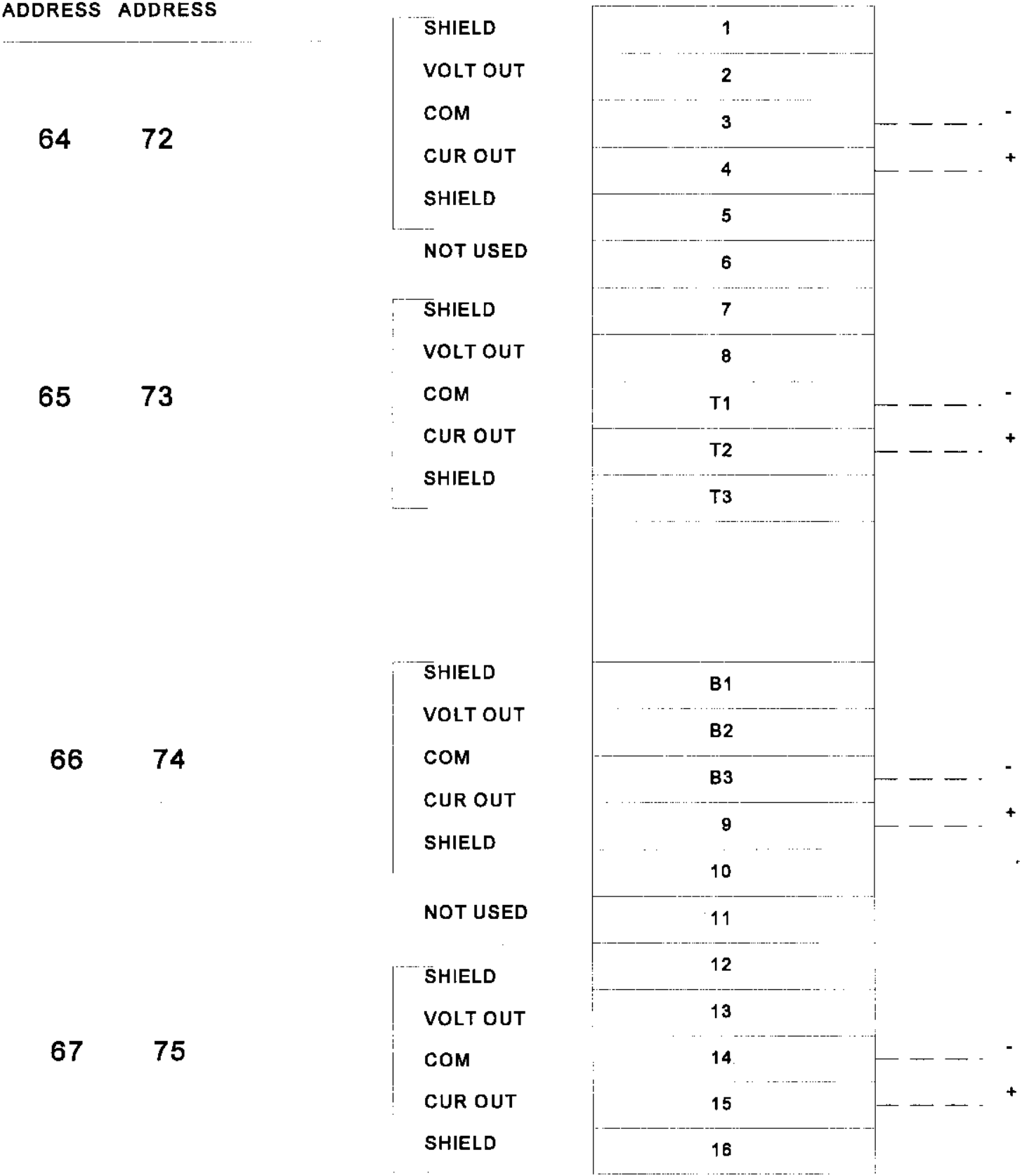




\begin{tabular}{|l|c|l||}
\hline ACCEPTANCE TEST & HONEYWELL MODULAR AUTOMATION & HNF-SD-CP-ATP-071 \\
PROCEDURE & SYSTEM & REV-2 \\
& & \\
& & \\
& & \\
\hline
\end{tabular}

Figure 5 - Digital Input Module Connection Schematic ADDRESS BO 81

82

83

84

85

86

87

88

89

90

91

92

93

94

95
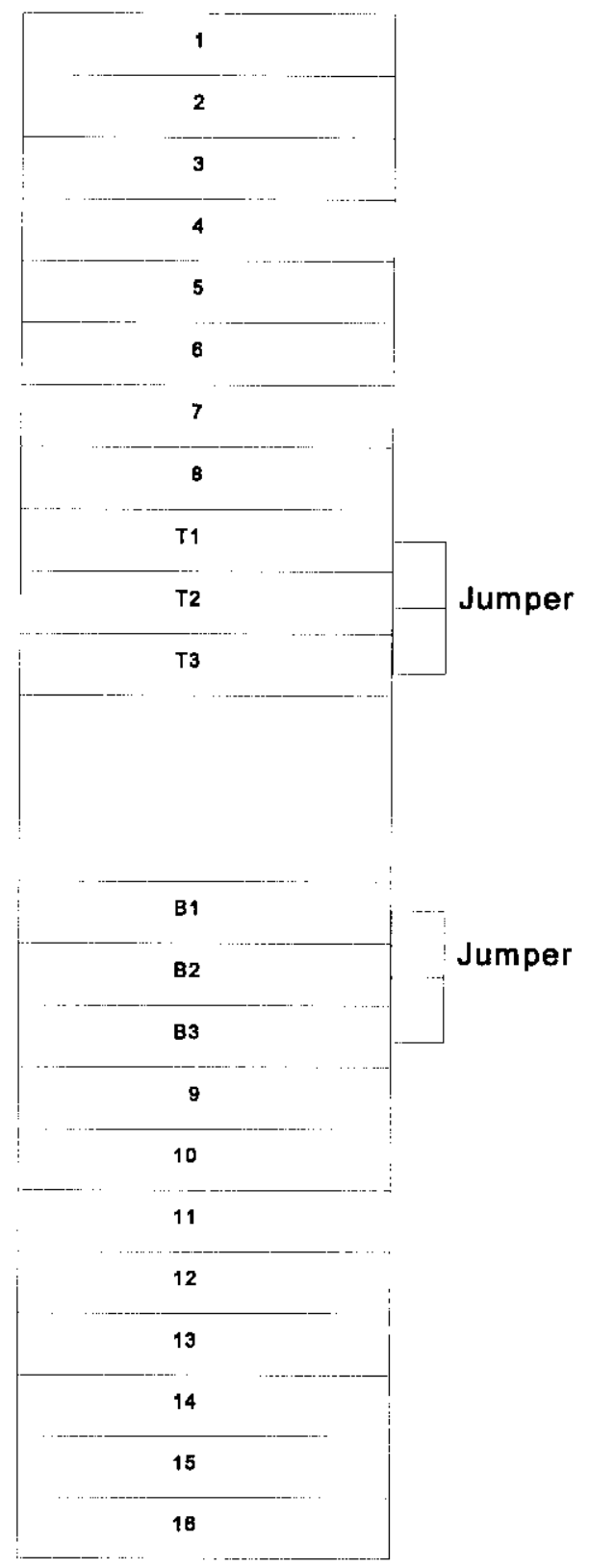


\begin{tabular}{|l|r|l|}
\hline $\begin{array}{l}\text { ACCEPTANCE TEST } \\
\text { PROCEDURE }\end{array}$ & $\begin{array}{r}\text { HONEYWELL MODULAR AUTOMATION } \\
\text { SYSTEM }\end{array}$ & $\begin{array}{l}\text { HNF-SD-CP-ATP-071 } \\
\text { REV-2 } \\
\text { PAGE 25 OF 29 }\end{array}$ \\
& & \\
\hline
\end{tabular}

Figure 6 - Digital Output Module Connection Schematic ADDRESS

96

97

98

99

100

101

102

103
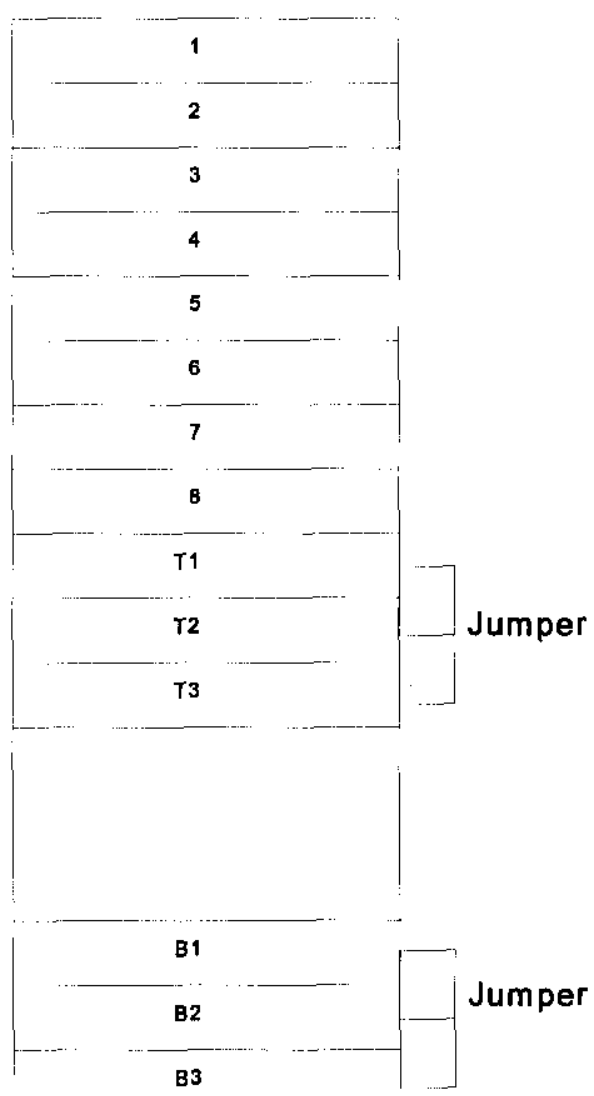

104

105

106

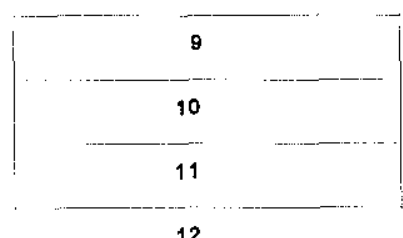

107

108

109

110

111

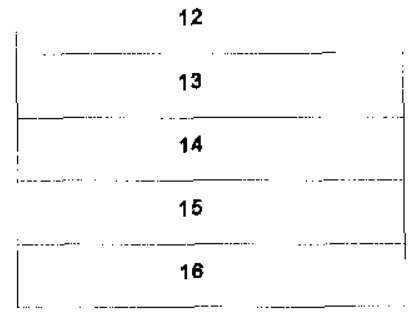




\begin{tabular}{|l|r|l|}
\hline $\begin{array}{l}\text { ACCEPTANCE TEST } \\
\text { PROCEDURE }\end{array}$ & HONEYWELL MODULAR AUTOMATION \\
& SYSTEM & HNF-SD-CP-ATP-071 \\
& REV-2 \\
& PAGE 26 OF 29 \\
\hline
\end{tabular}

APPENDIX B

TEST DATA SHEETS 


\begin{tabular}{|l|r|l||}
\hline ACCEPTANCE TEST & HONEYWELL MODULAR AUTOMATION & HNF-SD-CP-ATP-071 \\
PROCEDURE & SYSTEM & REV-2 \\
& & PAGE 27 OF 29 \\
\hline
\end{tabular}

Data Sheet 1 - HA-21I Temperature Inputs

Page 1 of 2

\begin{tabular}{|c|c|c|c|}
\hline STEP & ADDRESS & INPUT & DISPLAY \\
\hline \multirow[t]{3}{*}{8.3 .1} & \multirow[t]{3}{*}{0} & $25 \pm 0.2{ }^{\circ} \mathrm{C}$ & \\
\hline & & $200 \pm 0.2^{\circ} \mathrm{C}$ & \\
\hline & & $1000 \pm 0.2^{\circ} \mathrm{C}$ & \\
\hline \multirow[t]{3}{*}{8.3 .2} & \multirow[t]{3}{*}{1} & $25 \pm 0.2{ }^{\circ} \mathrm{C}$ & \\
\hline & & $200 \pm 0.2{ }^{\circ} \mathrm{C}$ & \\
\hline & & $1000 \pm 0.2^{\circ} \mathrm{C}$ & \\
\hline \multirow[t]{3}{*}{8.3 .3} & \multirow[t]{3}{*}{9} & $25 \pm 0.2{ }^{\circ} \mathrm{C}$ & \\
\hline & & $200 \pm 0.2^{\circ} \mathrm{C}$ & \\
\hline & & $1000 \pm 0.2^{\circ} \mathrm{C}$ & \\
\hline \multirow[t]{3}{*}{8.4 .1} & \multirow[t]{3}{*}{2} & $25 \pm 0.2{ }^{\circ} \mathrm{C}$ & \\
\hline & & $200 \pm 0.2^{\circ} \mathrm{C}$ & \\
\hline & & $1000 \pm 0.2{ }^{\circ} \mathrm{C}$ & \\
\hline \multirow[t]{3}{*}{8.4 .2} & \multirow[t]{3}{*}{3} & $25 \pm 0.2{ }^{\circ} \mathrm{C}$ & \\
\hline & & $200 \pm 0.2{ }^{\circ} \mathrm{C}$ & \\
\hline & & $1000 \pm 0.2^{\circ} \mathrm{C}$ & \\
\hline \multirow[t]{3}{*}{8.4 .3} & \multirow[t]{3}{*}{10} & $25 \pm 0.2^{\circ} \mathrm{C}$ & \\
\hline & & $200 \pm 0.2^{\circ} \mathrm{C}$ & \\
\hline & & $1000 \pm 0.2^{\circ} \mathrm{C}$ & \\
\hline \multirow[t]{3}{*}{8.5 .1} & \multirow[t]{3}{*}{4} & $25 \pm 0.2^{\circ} \mathrm{C}$ & \\
\hline & & $200 \pm 0.2^{\circ} \mathrm{C}$ & \\
\hline & & $1000 \pm 0.2{ }^{\circ} \mathrm{C}$ & \\
\hline
\end{tabular}




\begin{tabular}{||l|l|l||}
\hline ACCEPTANCE TEST & HONEYWELL MODULAR AUTOMATION \\
PROCEDURE & SYSTEM & HNF-SD-CP-ATP-071 \\
& REV-2 \\
& PAGE 28 OF 29 \\
& \\
\hline
\end{tabular}

\begin{tabular}{||c|c|c|c||}
\hline \hline STEP & ADDRESS & INPUT & DISPLAY \\
\hline \multirow{2}{*}{8.5 .2} & \multirow{2}{*}{5} & $25 \pm 0.2^{\circ} \mathrm{C}$ & \\
\cline { 3 - 4 } & & $200 \pm 0.2{ }^{\circ} \mathrm{C}$ & \\
\cline { 3 - 4 } & & $1000 \pm 0.2{ }^{\circ} \mathrm{C}$ & \\
\hline
\end{tabular}

NOTE - The display reading should be $\pm 0.5^{\circ} \mathrm{C}$ of the input value.

Comments 


\begin{tabular}{||l|c|l||}
\hline $\begin{array}{l}\text { ACCEPTANCE TEST } \\
\text { PROCEDURE }\end{array}$ & HONEYWELL MODULAR AUTOMATION \\
& SYSTEM & $\begin{array}{l}\text { HNF-SD-CP-ATP-071 } \\
\text { REV-2 } \\
\text { PAGE 29 OF } 29\end{array}$ \\
& \\
\hline
\end{tabular}

Data Sheet 1 - HA-21I Temperature Inputs

Page 2 of 2

\begin{tabular}{|c|c|c|c|}
\hline STEP & ADDRESS & INPUT & DISPLAY \\
\hline \multirow[t]{3}{*}{8.5 .3} & \multirow[t]{3}{*}{11} & $25 \pm 0.2{ }^{\circ} \mathrm{C}$ & \\
\hline & & $200 \pm 0.2^{\circ} \mathrm{C}$ & \\
\hline & & $1000 \pm 0.2{ }^{\circ} \mathrm{C}$ & \\
\hline \multirow[t]{3}{*}{8.6 .1} & \multirow[t]{3}{*}{6} & $25 \pm 0.2{ }^{\circ} \mathrm{C}$ & \\
\hline & & $75 \pm 0.2{ }^{\circ} \mathrm{C}$ & \\
\hline & & $100 \pm 0.2^{\circ} \mathrm{C}$ & \\
\hline \multirow[t]{3}{*}{8.6 .2} & \multirow[t]{3}{*}{7} & $25 \pm 0.2{ }^{\circ} \mathrm{C}$ & \\
\hline & & $75 \pm 0.2{ }^{\circ} \mathrm{C}$ & \\
\hline & & $100 \pm 0.2{ }^{\circ} \mathrm{C}$ & \\
\hline \multirow[t]{3}{*}{8.6 .3} & \multirow[t]{3}{*}{8} & $25 \pm 0.2^{\circ} \mathrm{C}$ & \\
\hline & & $75 \pm 0.2^{\circ} \mathrm{C}$ & \\
\hline & & $100 \pm 0.2{ }^{\circ} \mathrm{C}$ & \\
\hline
\end{tabular}

NOTE - The display reading should be $\pm 0.5{ }^{\circ} \mathrm{C}$ of the input value.

Test Performer

Signature/Date

Test Director

Signature/Date

Quality Control

Signature/Date

Comments 